\title{
Diastereoselective cycloaddition of bromonitrile oxide to sugar derived chiral alkenes. A possible route for the synthesis of higher deoxysugars
}

\author{
Evdoxia Coutouli-Argyropoulou, ${ }^{* a}$ Christos Kyritsis, ${ }^{a}$ and Milosz Ruszkowski ${ }^{b}$ \\ ${ }^{a}$ Department of Chemistry, Aristotle University of Thessaloniki, Thessaloniki, 54124, Greece \\ ${ }^{b}$ Erasmus student from A. Mickiewicz University, Poznan, Poland
}

E-mail:evd@chem.auth

\begin{abstract}
Bromonitrile oxide formed in situ from dibromoformaldoxime reacts with the sugar derived alkenes $\mathbf{1}, \mathbf{2}, \mathbf{3}, \mathbf{4}$, to give bromoisoxazolines in satisfactory yields. All the reactions show high regio- and stereoselectivity. Reactions with the $\omega$-unsaturated alkenes $\mathbf{1}$ and $\mathbf{2}$ are regiospecific and diastereoselective affording a pair of diastereomers. The reaction with furanone $\mathbf{4}$ is regioselective and stereospecific affording one pair of regioisomers, whereas the reaction with the glycal 3 is both regiospecific and stereospecific and gives only one isomer. The possible utility of the obtained isoxazolines as useful synthetic intermediates is further proved by transformation of isoxazoline 7 to 7-deoxy octose derivative $\mathbf{1 6 .}$
\end{abstract}

Keywords: Bromonitrile oxide, 1,3-dipolar cycloaddition, sugar-alkenes, glycal, deoxysugar

\section{Introduction}

Nitrile oxide-olefin cycloaddition is amongst the most widely studied reactions and it finds applications in numerous synthetic schemes, where the initially formed isoxazoline gives entry to other functionalities such as $\beta$-hydroxyketones by reductive cleavage of the N-O bond. ${ }^{1}$ Nitrile oxides bearing functional substituents on the carbon atom of the dipole such as bromo, chloro or carboalkoxy offer additional possibilities for transformations. In particular, the 1,3-dipolar cycloadditions of bromonitrile oxide have been used as key steps in synthetic schemes where nucleophilic substitution of bromine and/or reductive ring cleavage take place. ${ }^{2}$ Among the plethora of alkenes used in 1,3-dipolar cycloadditions, reactions of nitrile oxides to sugar derived alkenes concentrate considerable interest since they offer entry to a diversity of sugar mimics of biological interest such as higher monosaccharides, carbocyclic $C$-nucleosides, isoxazolino nucleosides and $C$-disaccharides. ${ }^{3}$ However, the flexible bromonitrile oxide has not been 
employed so far in 1,3-dipolar cycloadditons to sugar derived alkenes with the exception of one report with $\alpha, \beta$-unsaturated carbonyl sugar olefins. ${ }^{4}$

In connection with our former studies on nitrile oxide cycloadditions and sugar chemistry, ${ }^{5,6}$ we present our results on the 1,3-dipolar cycloaddition of bromonitrile oxide with the diverse sugar derived alkenes $1,2,3$ and 4 . Nitrile oxide cycloadditions to the $\omega$-unsaturated monosaccharides $\mathbf{1}$ and $\mathbf{2}$ have been successfully applied by Paton and coworkers for sugar elongation. Thus, by choosing carboethoxyformonitrile oxide or appropriate sugar derived nitrile oxides extension with two or more carbon atoms to their non-reducing terminus was possible. ${ }^{7}$ We considered that this methology can be extended to one carbon chain elongation using bromonitrile oxide as 1,3-dipole. On the contrary to alkenes $\mathbf{1}$ and $\mathbf{2}$, cycloaddition reactions of nitrile oxides to the cyclic derivatives $\mathbf{3}$ and $\mathbf{4}$ are almost completely unexplored to the best of our knowledge. The use of glycals as compound $\mathbf{3}$ in cycloaddition reactions is mainly focused on [2+2] and hetero Diels-Alder reactions, whereas there are only a few examples of 1,3-dipolar cycloadditions with cyclic nitrones, electron rich azides, 1,3-diaza-2-azoniallene salts and one example of an intramolecular cycloaddition of nitrone and nitrile oxide. ${ }^{8}$ Cycloaddition reactions to the furanone 4 are mainly referred to [2+2] cycloadditions, Diels-Alder reactions and 1,3dipolar cycloaddition of diazocompounds and nitrones. ${ }^{9}$

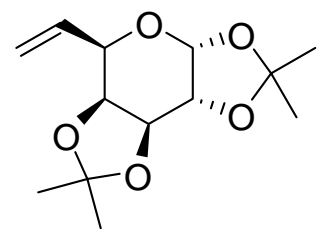

1

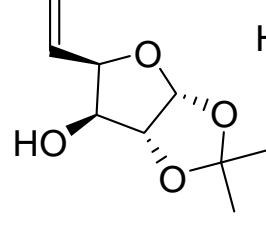

2<smiles>CO[C@H]1C=CO[C@H](COC(C)=O)[C@H]1OC(C)=O</smiles>

3

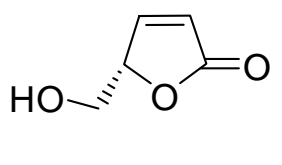

4

\section{Results and Discussion}

In all the cycloadditions studied (see Scheme 1), the bromonitrile oxide 6 was derived in situ from the dibromoformaldoxime $\mathbf{5}$ using solid sodium bicarbonate in the presence of the alkene in ethyl acetate solutions. In order to raise the reaction yields relative to the alkene the oxime $\mathbf{5}$ was used in excess. The reactions with the two $\omega$-unsaturated monosaccharides $\mathbf{1}$ and $\mathbf{2}$ took place at room temperature and each one gave two diastereomeric isoxazolidines $\mathbf{7 / 8}$ and $\mathbf{9 / 1 0}$ in $76 \%$ and $80 \%$ total yields and in ratios 8.5:1 and 8:1 respectively as determined by ${ }^{1} \mathrm{H}$ NMR of the crude reaction mixture. From the reaction mixtures the major isomers $\mathbf{7}$ and $\mathbf{9}$ were separated in pure form by column chromatography, whereas the minor isomers $\mathbf{8}$ and $\mathbf{1 0}$ were obtained only as mixtures with the major ones. The structure elucidation of the obtained cyclodducts was mainly based on their ${ }^{1} \mathrm{H}$ NMR spectra, in which the proton connection was secured by double resonance experiments besides their coupling constants. 


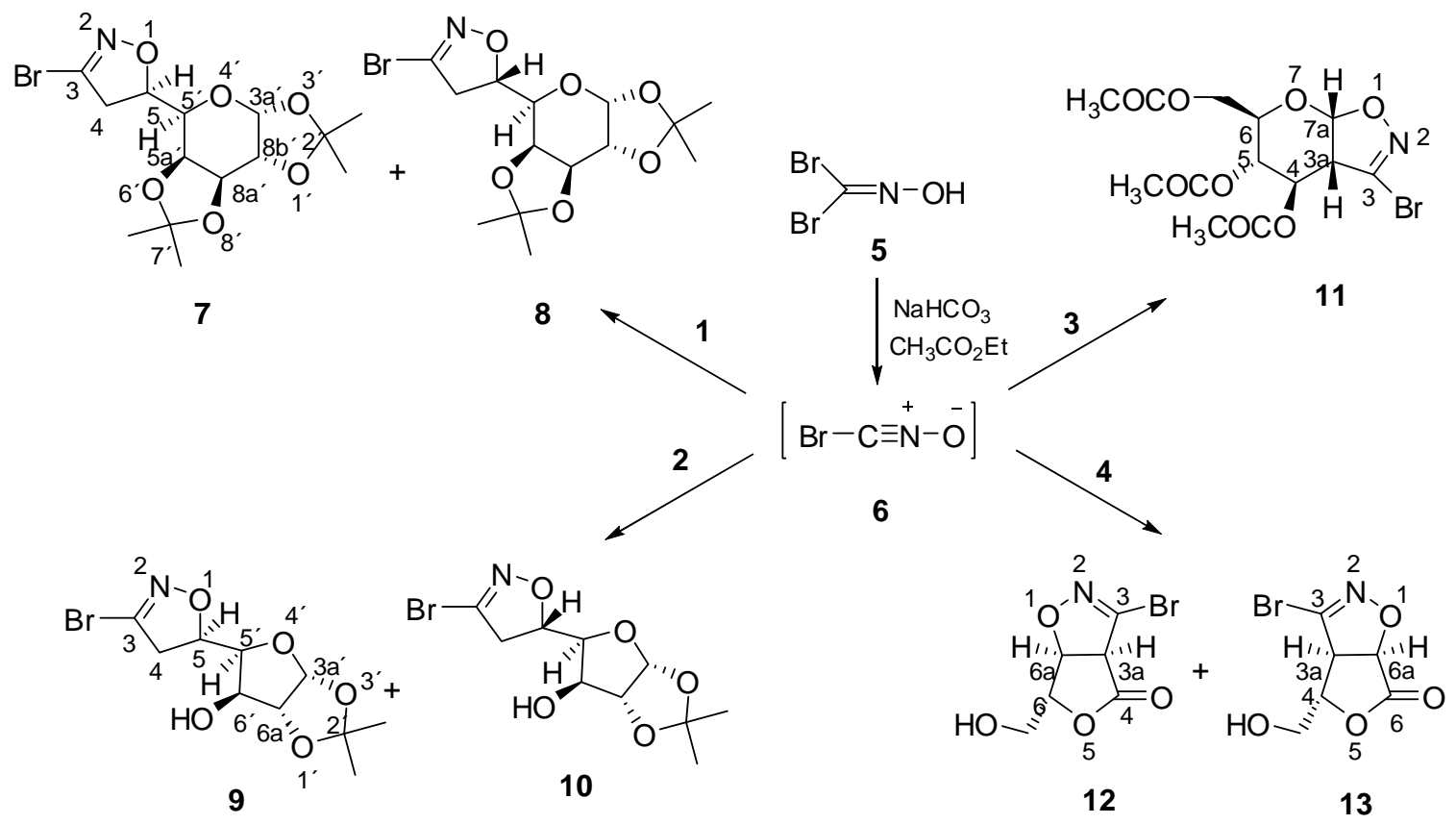

\section{Scheme 1}

All the obtained cycloadducts were safely assigned as 5-substituted regioisomers on the basis of their characteristic pattern of isoxazoline ring protons, typical of a 3,5-disubstituted isoxazoline. Thus the 5-H appear as doublets of triplets at high $\delta 4.84-5.05$, whereas the $4-\mathrm{H}$ appear as doublets at low $\delta 3.28-3.48$. Between the two diastereomeric pairs of cycloaddition products the major isomers were assigned as structures 7 and $\mathbf{9}$ with an $R$-configuration at the newly created asymmetric center $\mathrm{C}-5$ and an erythro relationship between this carbon and the adjacent carbon $\left(\mathrm{C}-5^{\prime}\right)$. This assignment was based on ${ }^{1} \mathrm{H}$ and ${ }^{13} \mathrm{C} \mathrm{NMR}$ chemical shift regularities employed in analogous cases to assign the stereochemistry of diastereomeric pairs of isoxazolines resulting from cycloaddition reactions of nitrile oxides to carbohydrate alkenes. ${ }^{7 \mathrm{c}}$ Some of these regularities could be observed between the chemical shifts of the diastereomeric pairs 7/8 and 9/10. Thus, the signals of $3 \mathrm{a}^{\prime}-\mathrm{H}$ and $5^{\prime}-\mathrm{H}$ appear at lower chemical shifts for the major isomers. The chemical shifts of $3 \mathrm{a}^{\prime}-\mathrm{H}$ and $5^{\prime}-\mathrm{H}$ of isomer 7 are at $\delta 5.51$ and 3.79, whereas those of isomer 8 at $\delta 5.56$ and 3.95 respectively. Similarly, the chemical shifts of $3 \mathrm{a}^{\prime}-\mathrm{H}$ and $5^{\prime}-$ $\mathrm{H}$ of isomer 9 are at $\delta 5.90$ and 4.16, whereas those of isomer $\mathbf{1 0}$ at $\delta 5.97$ and 4.20 respectively. Also in the ${ }^{13} \mathrm{C}$ NMR the safely distinctive signals of C-4 appear at higher frequencies for the major isomers. The chemical shift for C-4 of isomer 7 is at $\delta 43.9$, whereas that of isomer 8 at $\delta$ 43.2. Similarly, the chemical shift for the C-4 of isomer 9 is at $\delta 44.6$, whereas that of isomer 10 at $\delta$ 44.3. The proposed stereochemistry for compound 7 was further supported via its transformation products as described below. The observed stereoslectivity of the addition is that which would expected based on steric arguments, as it comes out from molecular model examination. This stereoselectivity associated with the addition of nitrile oxides to chiral allyl 
ethers can be furthermore rationalized in terms of the "inside alkoxy effect" proposed by Houk and al. ${ }^{10}$

Glycal $\mathbf{3}$ was less reactive than the open chain alkenes $\mathbf{1}$ and $\mathbf{2}$ and reacted with bromonitrile oxide 6 in satisfactory yield only after prolonged heating (reflux for 8 days). For the optimization of the reaction yield relative to the glycal, dibromoformaldoxime was used in a large excess and it was added in small portions during the reaction time. The reaction was regio- and stereospecific and only one cycloadduct was formed assigned as $\mathbf{1 1}$. The spectral and analytical data of compound $\mathbf{1 1}$ are in accordance with the proposed structure. In particular, the assignment of the regio- and stereochemistry of $\mathbf{1 1}$ was mainly based on its ${ }^{1} \mathrm{H}$ NMR spectrum. The low field doublet at $\delta 6.11$ observed for the acetal proton $7 \mathrm{a}-\mathrm{H}$ is consistent with the proposed regiochemistry. The proposed stereochemistry of the cycloaddition is in accordance with the usually observed stereoselectivity in the cycloaddition reactions of glycals in which the pseudoequatorial group on $\mathrm{C}-3$ of the glycal controls the stereochemistry of the cycloaddition favoring the approach to the opposite site of this substituent. ${ }^{8 c, 8 \mathrm{e}}$ The trans relationship of the isoxazoline ring to the vicinal acetoxy group is supported by the low coupling constant $(J=2.6$ $\mathrm{Hz}$ ) between $3 \mathrm{a}-\mathrm{H}$ and $4-\mathrm{H}$. The set of coupling constants observed for compound 11 gives further information for the conformation of the cyclohexane ring and fits only to trans substitution on $\mathrm{C}-3 \mathrm{a}$ and $\mathrm{C}-4$ and a pyranose ring in a twist conformation. The large coupling constant $(J=8.9 \mathrm{~Hz})$ between the anomeric $7 \mathrm{a}-\mathrm{H}$ and $3 \mathrm{a}-\mathrm{H}$ is in agreement with a dihedral angle $\alpha_{\mathrm{H}-3 \mathrm{a}, 7 \mathrm{a}-\mathrm{H}}$ about $0^{\circ}$ and the small coupling constant $J_{4-\mathrm{H}, 5-\mathrm{H}}=1.4 \mathrm{~Hz}$ is indicative of a dihedral angle close to $90^{\circ}$ and not $180^{\circ}$ for antiperiplanar position as it should be in a chair conformation. On the contrary, the $J_{5-\mathrm{H}, 6-\mathrm{H}}=7.5 \mathrm{~Hz}$ is larger than that expected in a chair conformation. Besides, a ${ }^{4} J-(\mathrm{W})$ coupling $(1.4 \mathrm{~Hz})$ was observed between $3 \mathrm{a}-\mathrm{H}$ and $5-\mathrm{H}$ in accordance with the proposed conformation as depicted in figure 1 . Analogous ${ }^{4} J-(\mathrm{W})$ couplings have been observed in cyclohexanes with twist-boat conformations, ${ }^{11}$ whereas this conformation has been also proposed for the cycloaddition product of glycal 3 with 1,3-diaza-2-azoniallene salts. ${ }^{8 \mathrm{e}}$ Furthermore NOE difference measurements showed significant intensity enhancements (10$20 \%$ )only between the pair of vicinal protons and not between $5-\mathrm{H}$ and $3 \mathrm{a}-\mathrm{H}$ or $7 \mathrm{a}-\mathrm{H}$.

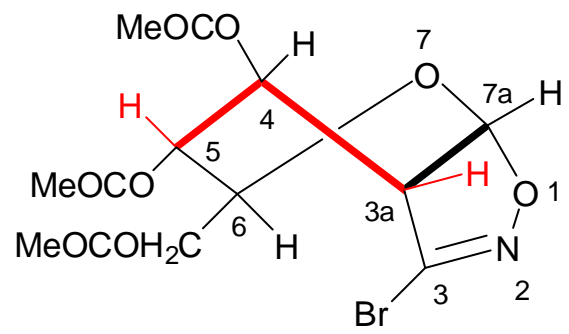

Figure 1. Twist conformation of compound $\mathbf{1 1}$ with a $\mathrm{W}$ connectivity of $3 \mathrm{a}-\mathrm{H}$ and 5-H.

Furanone 4 bearing an activating carbonyl was more reactive than glycal 3 and its reaction with the bromonitrile oxide took place at room temperature and gave the regioisomers $\mathbf{1 2}$ and $\mathbf{1 3}$ 
in a ratio $6: 1$ and in $77 \%$ total yield. From the reaction mixture the major isomer 12 was obtained in a pure form by column chromatography, whereas the minor isomer $\mathbf{1 3}$ was contaminated with a small amount of the major one. The assignment of both $\mathbf{1 2}$ and $\mathbf{1 3}$ as anti cycloadducts was based on the observed small coupling constants $J_{6-\mathrm{H}, 6 \mathrm{a}-\mathrm{H}}=1.3 \mathrm{~Hz}$ of $\mathbf{1 2}$ and and $J_{3 \mathrm{a}-\mathrm{H}, 4-\mathrm{H}} \approx 0 \mathrm{~Hz}$ of 13 , which are informative for the trans orientation of the corresponding protons. ${ }^{9 b, 9 \mathrm{c}}$ The distinction between the two regioisomers was made on the basis of their proton and carbon chemical shifts. In particular, in the minor isomer $\mathbf{1 3}$ both proton and carbon of the 4 position of isoxazoline ring next to a saturated carbon atom are expected to be upfield compared to those of the major isomer 12, where the 4-isoxazoline position is next to a carbonyl group. Indeed the 3a-H of $\mathbf{1 3}$ resonates at $\delta 4.13$ whereas that of $\mathbf{1 2}$ at $\delta 4.32$. Also the C-3a of $\mathbf{1 3}$ resonates at 56.9 whereas that of $\mathbf{1 2}$ at $\delta 59.2$. Our findings are in accordance with the observed selectivities of the 1,3-dipolar cycloadditions of nitrones to lactone 4 , in which the oxygen atom selectively attacks the $\beta$-carbon of the unsaturated moiety of $\mathbf{4}$ and show high preference for an anti addition to the terminal hydroxymethyl group of the lactone. ${ }^{9 a, 9 e, 9 f}$

We have also examined the utility of the obtained cycloadducts for further sugar derivations applying isoxazoline ring transformations on the cycloadduct 7 as shown in Scheme 2. Thus, nucleophilic substitution of the bromine gave the methoxy derivative 14. The methoxylation was carried out under smooth reaction conditions using potassium carbonate at room temperature. Under these conditions no epimerization at the newly asymmetric center (C-5) occurs as it was shown by experiments, in which mixtures of the two isomers in different ratios were transformed to methoxy derivatives with retention of the ratio. Substitution of bromine by methoxy group has been successfully applied to a variety of bromoisoxazolines in reaction schemes for the conversion of isoxazolines to $\beta$-hydroxy esters, ${ }^{2 a}$ although there are reports where this methology has failed. ${ }^{2 \mathrm{e}}$ For the next reductive cleavage of the isoxazoline ring typical reduction conditions were applied ( $\mathrm{Ra} / \mathrm{Ni}, \mathrm{H}_{2}$, boric acid). The reaction was proved to be quite sensitive and the ester 15 was obtained in high yield only after careful cleaning of the catalyst and control of the reaction time. Finally the reduction to the alcohol $\mathbf{1 6}$ proceeded without any problems with $\mathrm{LiBH}_{4}$. Thus, following the reaction sequence of Scheme 2 bromonitrile cycloaddition to sugar alkenes can be applied for one carbon stereocontrolled elongation of unsaturated monosaccharides complementing the methology applied by Paton and coworkers for elongation with two or more carbon atoms. ${ }^{7}$ 


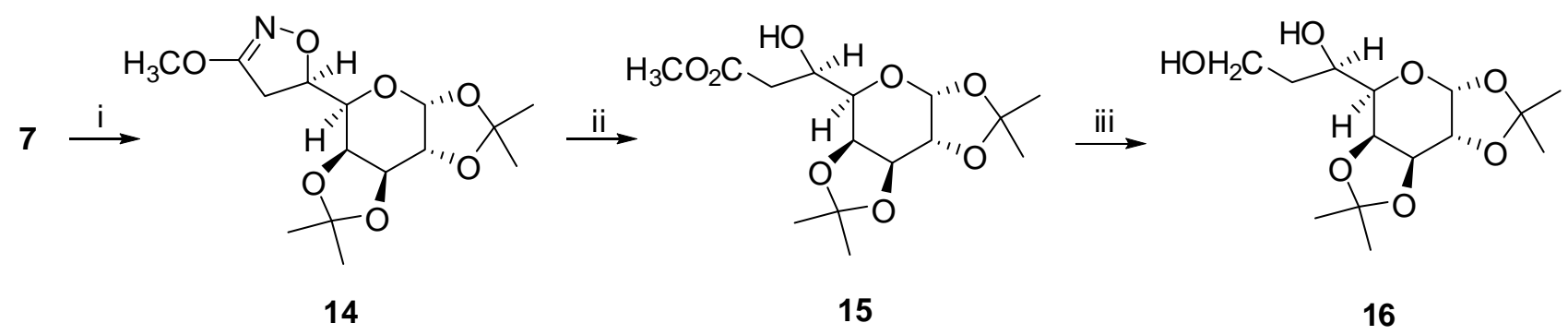

Scheme 2. Reagents and conditions: (i) $\mathrm{CH}_{3} \mathrm{OH}, \mathrm{K}_{2} \mathrm{CO}_{3}, \mathrm{RT}, 3$ days. (ii) $\mathrm{Ra} / \mathrm{Ni}, \mathrm{H}_{2}, \mathrm{CH}_{3} \mathrm{OH}, \mathrm{RT}, 2 \mathrm{~h}$. (iii) $\mathrm{LiBH}_{4}, \mathrm{Et}_{2} \mathrm{O}, 0^{\circ} \mathrm{C}, 2 \mathrm{~h}$.

All the obtained transformation products were characterized on the basis of their spectral and analytical data. In addition, the stereoshemistry of the ester $\mathbf{1 5}$ was supported by the coincidence of its ${ }^{1} \mathrm{H}$ NMR spectra data with those given in the literature for the same isomer obtained from an aldol reaction of a D-galacto-dialdopyranose derivative and acetyl iron complex. ${ }^{12}$ This fact gives further evidence for the stereochemical assignment of the initial cycloaddition product 7.

\section{Conclusions}

In conclusion, bromonitrile oxide can give cycloaddition products in good yields with both open chain and cyclic alkenes derived from sugars even with an alkene of low dipolarophilicity, such as the glycal 3. All the reactions show high regio and stereoselectivity. With the exception of furanone 4, the reactions with the other alkenes are regiospecific giving only isoxazolines in which the oxygen is attached to the more substituted carbon in the reactions with alkenes $\mathbf{1}$ and $\mathbf{2}$ or to the carbon next to the oxygen in the reaction with alkene 3 . The reactions of cyclic alkenes show stereospecificity and give products in which the dipolarophile approaches to the anti face to the substituent next to the double bond. The obtained cycloadducts can be used as intermediates for further derivation of sugars and stereocontrolled one carbon elongation.

\section{Experimental Section}

General. Melting points are uncorrected and were determined on a Kofler hot-stage microscope. The IR spectra were obtained with a Perkin-Elmer 297 spectrophotometer, as a thin film or nujol mull as indicated. ${ }^{1} \mathrm{H}$ NMR spectra were recorded at $300 \mathrm{MHz}$ on a Bruker $300 \mathrm{AM}$ spectrometer and ${ }^{13} \mathrm{C}$ NMR spectra at $75.5 \mathrm{MHz}$ on the same spectrometer, and are quoted relative to tetramethylsilane as internal reference in deuteriochloroform solutions. Low-resolution electron impact mass spectra were recorded on a 6890N GC/MS system (Agilent technology) and elemental analyses performed with a Perkin-Elmer 2400-II CHN analyzer. Column chromatography was carried out on Merck Kieselgel (particle size 0.063-0.200 mm) and solvents 
were distilled before use. All reactions were monitored by TLC using Merck Kiesegel $60 \mathrm{~F}_{254}$ plates. Optical rotations were measured with a A. KRÜSS Optronic P3002, operating at $589 \mathrm{~nm}$ $\left(1=1 \mathrm{dm}, 25^{\circ} \mathrm{C}\right)$. Dibromoformaldoxime $\mathbf{5}$ was prepared as referred in the literature. ${ }^{13 a}$ Alkenes $1,{ }^{13 \mathrm{~b}} \mathbf{2}^{13 \mathrm{~b}}$ and $\mathbf{4}^{13 \mathrm{c}}$ were prepared starting from D-galactose, D-glucose and D-mannitol respectively, whereas glycal $\mathbf{3}$ was commercially available.

\section{Cycloaddition reaction to alkene 1}

Alkene $1(256 \mathrm{mg}, 1 \mathrm{mmol})$ was dissolved in ethyl acetate $(10 \mathrm{~mL})$ and there were added $\mathrm{NaHCO}_{3}(504 \mathrm{mg}, 6 \mathrm{mmol})$ and dibromoformaldoxime $(305 \mathrm{mg}, 1.5 \mathrm{mmol})$. The reaction mixture was stirred at room temperature for 5 days. After the solids were removed by filtration, the filtrate was concentrated and the residue was chromatographed on a silica gel column with hexane/ethyl acetate 8:1 as the eluent. From the column there were obtained in order of elution: compound $7(200 \mathrm{mg})$, mixture of $\mathbf{7}$ and 8 in ratio 5:1 $(60 \mathrm{mg})$ and a mixture of $\mathbf{7}$ and $\mathbf{8}$ in a ratio $1: 3(27 \mathrm{mg})$.

(5R)-3-Bromo-5-[(3a' $\left.R, 5^{\prime} S, 5 \mathrm{a}^{\prime} S, 8 \mathrm{a}^{\prime} S, 8 \mathrm{~b}^{\prime} R\right)-2^{\prime}, 2^{\prime}, 7^{\prime}, 7^{\prime}$-tetramethyltetrahydro-3a' $H$ bis[1,3]dioxolo[4,5-b:4',5'-d]pyran-5'-yl]-4,5-dihydroisoxazole (7). This compound was obtained as white solid $\mathrm{mp} 103-105{ }^{\circ} \mathrm{C}$ in $68 \%$ yield. $[\alpha]_{\mathrm{D}}{ }^{25}=-168.5^{\circ}\left(\mathrm{c} \quad 1.15, \mathrm{CHCl}_{3}\right)$. IR (Nujol): v 1650 (w), 1240(s), 1200(s), $1150(\mathrm{~s}), 1060$ (vs), 990 (s) $\mathrm{cm}^{-1} .{ }^{1} \mathrm{H}$ NMR $\left(\mathrm{CDCl}_{3}\right): \delta$ $1.33\left(\mathrm{~s}, 3 \mathrm{H}, \mathrm{CH}_{3}\right), 1.36\left(\mathrm{~s}, 3 \mathrm{H}, \mathrm{CH}_{3}\right), 1.45\left(\mathrm{~s}, 3 \mathrm{H}, \mathrm{CH}_{3}\right), 1.51\left(\mathrm{~s}, 3 \mathrm{H}, \mathrm{CH}_{3}\right), 3.29$ (d, $J=9.0 \mathrm{~Hz}$, 2H, 4-H), 3.79 (d, $\left.J=7.7 \mathrm{~Hz}, 1 \mathrm{H}, 5^{\prime}-\mathrm{H}\right), 4.33$ (dd, $J=5.1,2.3 \mathrm{~Hz}, 1 \mathrm{H}, 8 \mathrm{~b}^{\prime}-\mathrm{H}$ ), 4.37 (d, $J=7.7$ $\left.\mathrm{Hz}, 1 \mathrm{H}, 5 \mathrm{a}^{\prime}-\mathrm{H}\right), 4.63\left(\mathrm{dd}, J=7.7,2.3 \mathrm{~Hz}, 1 \mathrm{H}, 8 \mathrm{a}^{\prime}-\mathrm{H}\right), 4.86(\mathrm{dt}, J=9.0,7.7 \mathrm{~Hz}, 1 \mathrm{H}, 5-\mathrm{H}), 5.51$ $\left(\mathrm{d}, J=5.1 \mathrm{~Hz}, 1 \mathrm{H}, 3 \mathrm{a}^{\prime}-\mathrm{H}\right) .{ }^{13} \mathrm{C} \mathrm{NMR}\left(\mathrm{CDCl}_{3}\right): \delta 24.3(\mathrm{q}), 24.8(\mathrm{q}), 25.7(\mathrm{q})$ and $25.9(\mathrm{q})\left(\mathrm{CH}_{3}\right)$, 43.9 (t, C-4), 67.2 (d), 70.1 (d), 70.3 (d), 70.4 (d) and 79.3 (d) (C-5, C-5', C-5a', C-8a' and C-

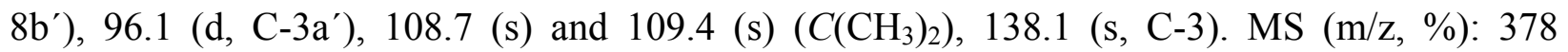
$\left[(\mathrm{M}+\mathrm{H})^{+}, 35 \%\right.$. Anal. calcd. for $\mathrm{C}_{14} \mathrm{H}_{20} \mathrm{BrNO}_{6}: \mathrm{C}, 44.46 ; \mathrm{H}, 5.33 ; \mathrm{N}, 3.70$. Found: $\mathrm{C}, 44.62 ; \mathrm{H}$, $5.07 ; \mathrm{N}, 3.63$.

(5S)-3-Bromo-5-[(3a' $\left.R, 5^{\prime} S, 5 a^{\prime} S, 8 a^{\prime} S, 8 b^{\prime} R\right)-2^{\prime}, 2^{\prime}, 7^{\prime}, 7^{\prime}$-tetramethyltetrahydro-3a' $H$ -

bis[1,3]dioxolo[4,5-b:4',5'-d]pyran-5'-yl]-4,5-dihydroisoxazole (8). This compound was obtained only as a mixture with 7 in $8 \%$ yield. ${ }^{1} \mathrm{H}$ NMR $\left(\mathrm{CDCl}_{3}\right): \delta 1.31\left(\mathrm{~s}, \mathrm{CH}_{3}\right), 1.33\left(\mathrm{~s}, \mathrm{CH}_{3}\right)$, $1,33\left(\mathrm{~s}, \mathrm{CH}_{3}\right), 1.36\left(\mathrm{~s}, 3 \mathrm{H}, \mathrm{CH}_{3}\right), 1.45\left(\mathrm{~s}, 3 \mathrm{H}, \mathrm{CH}_{3}\right), 1.51\left(\mathrm{~s}, 3 \mathrm{H}, \mathrm{CH}_{3}\right), 1.52\left(\mathrm{~s}, \mathrm{CH}_{3}\right), 1.61(\mathrm{~s}$, $\mathrm{CH}_{3}$ ), 3.19-3.39 (m, 4-H of 7 and 8), 3.79 (d, $J=7.7 \mathrm{~Hz}, 5^{\prime}-\mathrm{H}$ of 7), 3.95 (d, $J=7.1 \mathrm{~Hz}, 5^{\prime}-\mathrm{H}$ of

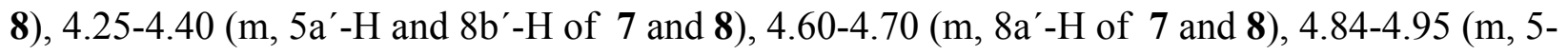
$\mathrm{H}$ of 7 and 8), $5.51\left(\mathrm{~d}, J=5.1 \mathrm{~Hz}, 3 \mathrm{a}^{\prime}-\mathrm{H}\right.$ of 7$), 5.56\left(\mathrm{~d}, J=5.1 \mathrm{~Hz}, 3 \mathrm{a}^{\prime}-\mathrm{H}\right.$ of 8). ${ }^{13} \mathrm{C}$ NMR $\left(\mathrm{CDCl}_{3}\right): \delta 24.2(\mathrm{q}), 24.3(\mathrm{q}), 24.8(\mathrm{q}), 25.7(\mathrm{q}), 25.8(\mathrm{q}), 25.9(\mathrm{q}), 26.0(\mathrm{q})$ and $26.1(\mathrm{q})\left(\mathrm{CH}_{3}\right)$, $43.2(\mathrm{t})$ and $43.9(\mathrm{t})(\mathrm{C}-4$ of 8 and 7), $67.2(\mathrm{~d}), 67.4(\mathrm{~d}), 70.1(\mathrm{~d}), 70.2(\mathrm{~d}), 70.3(\mathrm{~d}), 70.4(\mathrm{~d}), 70.6$ (d), 70.8 (d), 79.3 (d) and 80.7 (d) (C-5, C-5', C-5a', C-8a' and C-8b'), 96.1 (d) and 96.2 (d) (C-

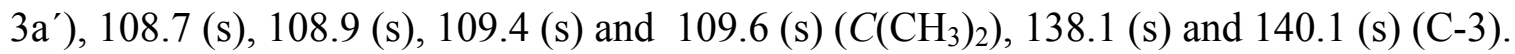




\section{Cycloaddition reaction to alkene 2}

The same procedure as for the reaction with alkene 1 was followed. Column chromatography with hexane/ethyl acetate $3: 1$ as the eluent gave in order of elution: compound 9 (170 $\mathrm{mg}$ ), mixture of 9 and $\mathbf{1 0}$ in ratio 4:1 (56 $\mathrm{mg}$ ) and a mixture of 9 and $\mathbf{1 0}$ in a ratio 1:4 (20 mg).

$\left(3 a^{\prime} R, 5^{\prime} S, 6^{\prime} S, 6 a^{\prime} R\right)-5 '-[(5 R)-3-B r o m o-4,5-d i h y d r o i s o x a z o l-5-y l]-2,2-d i m e t h y l t e t r a$ hydrofuro[2,3-d][1,3]dioxol-6' ${ }^{\prime}-01$ (9). This compound was obtained as as white solid mp 125$130{ }^{\circ} \mathrm{C}$ (under decomposition) in $71 \%$ yield. $[\alpha]_{\mathrm{D}}{ }^{25}=-152.6\left(c 0.58, \mathrm{CHCl}_{3}\right)$. IR (Nujol): $v 3400$ (s), $1640(\mathrm{w}), 1300(\mathrm{~s}), 1260(\mathrm{~m}), 1215(\mathrm{~s}), 1180(\mathrm{~m}), 1150(\mathrm{~s}), 1100$ (s), $990(\mathrm{~s}) \mathrm{cm}^{-1}$. ${ }^{1} \mathrm{H}$ NMR $\left(\mathrm{CDCl}_{3}\right): \delta 1.29\left(\mathrm{~s}, 3 \mathrm{H}, \mathrm{CH}_{3}\right), 1.46\left(\mathrm{~s}, 3 \mathrm{H}, \mathrm{CH}_{3}\right), 2.93($ br s, $1 \mathrm{H}, \mathrm{OH}), 3.33(\mathrm{~d}, J=9.0 \mathrm{~Hz}, 2 \mathrm{H}, 4-$ H), 4.16 (dd, $\left.J=7.7,2.9 \mathrm{~Hz}, 1 \mathrm{H}, 5^{\prime}-\mathrm{H}\right), 4.31$ (br s, 1H, 6'-H), 4.52 (d, $\left.J=3.9 \mathrm{~Hz}, 1 \mathrm{H}, 6 \mathrm{a}^{\prime}-\mathrm{H}\right)$, $4.92(\mathrm{dt}, J=9.0,7.7 \mathrm{~Hz}, 1 \mathrm{H}, 5-\mathrm{H}), 5.90\left(\mathrm{~d}, J=3.9 \mathrm{~Hz}, 1 \mathrm{H}, 3 \mathrm{a}^{\prime}-\mathrm{H}\right) .{ }^{13} \mathrm{C} \mathrm{NMR}\left(\mathrm{CDCl}_{3}\right): \delta 26.1$ (q) and 26.8 (q) $\left(\mathrm{CH}_{3}\right), 44.6(\mathrm{t}, \mathrm{C}-4), 74.1$ (d), $78.3(\mathrm{~d}), 80.4(\mathrm{~d})$ and 84.9 (d) (C-5, C-5', C-6' and C-6a), 104.6 (d, C-3a'), 112.0 (s, C( $\left.\left(\mathrm{CH}_{3}\right)_{2}\right), 138.4$ (s, C-3). MS (m/z, \%): 308 [(M+H) ${ }^{+}, 38 \%$ \% Anal. calcd. for $\mathrm{C}_{10} \mathrm{H}_{13} \mathrm{BrNO}_{5}$ : C, 39.11; H, 4.27; N, 4.56. Found: C, 38.92; H, 4.07; N, 4.63.

((3a'R,5'S,6'S,6a'R)-5'-[(5S)-3-Bromo-4,5-dihydroisoxazol-5-yl]-2,2-dimethyltetra

hydrofuro[2,3-d][1,3]dioxol-6' - ol (10). This compound was obtained only as a mixture with 9 in $9 \%$ yield. ${ }^{1} \mathrm{H}$ NMR $\left(\mathrm{CDCl}_{3}\right): \delta 1.29\left(\mathrm{~s}, \mathrm{CH}_{3}\right), 1.46\left(\mathrm{~s}, \mathrm{CH}_{3}\right), 1.49\left(\mathrm{~s}, \mathrm{CH}_{3}\right), 2.97(\mathrm{br}, \mathrm{OH})$, $3.28-3.48$ (m , 4-H of 9 and 10), $4.16\left(\mathrm{dd}, J=7.7,2.9 \mathrm{~Hz}, 5^{\prime}-\mathrm{H}\right.$ of 9), 4.21 (t, $J=3.8 \mathrm{~Hz}, 5^{\prime}-\mathrm{H}$ of 10), 4.25-4.32 (m, 6'-H of 9 and 10), 4.50-4.55 (m, 6a' $-\mathrm{H}$ of 9 and 10), 4.92 (dt, $J=9.0,7.7$ $\mathrm{Hz}, 5-\mathrm{H}$ of 9), 5.05 (ddd, $J=11.6,7.7,3.8 \mathrm{~Hz}, 5-\mathrm{H}$ of 10), 5.90 (d, $J=3.9 \mathrm{~Hz}, 3 \mathrm{a}^{\prime}-\mathrm{H}$ of 9), $5.97\left(\mathrm{~d}, J=3.9 \mathrm{~Hz}, 3 \mathrm{a}^{\prime}-\mathrm{H}\right.$ of 10). ${ }^{13} \mathrm{C} \mathrm{NMR}\left(\mathrm{CDCl}_{3}\right): \delta 26.0(\mathrm{q}), 26.1(\mathrm{q}), 26.7$ (q) and 26.8 (q) $\left(\mathrm{CH}_{3}\right), 44.3(\mathrm{t})$ and $44.6(\mathrm{t})\left(\mathrm{C}-4^{\prime}\right.$ of 10 and 9), $73.4(\mathrm{~d}), 74.1(\mathrm{~d}), 76.1(\mathrm{~d}), 78.3(\mathrm{~d}), 80.2(\mathrm{~d}), 80.4$ (d), 84.9(d) and 85.6 (d) (C-5, C-5', C-6' and C-6a'), 104.6 (d) and 104.8 (d) (C-3a'), 111.6 (s) and $112.0(\mathrm{~s})\left(C\left(\mathrm{CH}_{3}\right)_{2}\right), 138.4(\mathrm{~s})$ and $140.0(\mathrm{~s})(\mathrm{C}-3)$.

\section{Cycloaddition reaction to alkene 3}

Glycal 3 (272 $\mathrm{mg}, 1 \mathrm{mmol})$ was dissolved in ethyl acetate $(10 \mathrm{~mL})$ and there were added $\mathrm{NaHCO}_{3}$ (336 mg, $4 \mathrm{mmol}$ ) and dibromoformaldoxime (203 mg, $1 \mathrm{mmol}$ ). The reaction mixture was stirred and heated under reflux for 9 days. During this period there were added in small portions more $\mathrm{NaHCO}_{3}(3 \mathrm{x} 42 \mathrm{mg}, 6 \mathrm{mmol})$ and dibromoformaldoxime (3 x $\left.101 \mathrm{mg}, 1.5 \mathrm{mmol}\right)$. After the solids were removed by filtration, the filtrate was concentrated and the residue was chromatographed on a silica gel column with hexane/ethyl acetate 3:2 as the eluent. From the column there was obtained compound $11(275 \mathrm{mg})$.

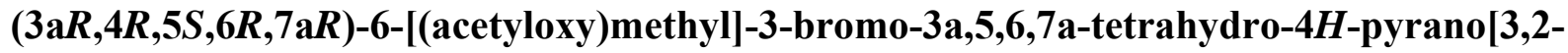

d]isoxazole-4,5-diyl diacetate (11). This compound was obtained as an oil in $70 \%$ yield. [ $\alpha]_{\mathrm{D}}{ }^{25}$ $=-67.1^{\circ}$ (c 4.22, $\mathrm{CHCl}_{3}$ ). IR (Neat): $v 1725$ (vs), $1560(\mathrm{w}), 1300(\mathrm{~s}), 1260(\mathrm{~m}), 1220$ (vs), 1120 (s), $1025(\mathrm{~s}) \mathrm{cm}^{-1} .{ }^{1} \mathrm{H}$ NMR $\left(\mathrm{CDCl}_{3}\right) \delta 2.10\left(\mathrm{~s}, 3 \mathrm{H}, \mathrm{CH}_{3}\right), 2.11\left(\mathrm{~s}, 3 \mathrm{H}, \mathrm{CH}_{3}\right), 2.15\left(\mathrm{~s}, 3 \mathrm{H}, \mathrm{CH}_{3}\right)$, 3.66 (ddd, $J=8.9,2.6,1.4 \mathrm{~Hz}, 1 \mathrm{H}, 3 \mathrm{a}-\mathrm{H}), 3.81$ (ddd, $J=7.5,5.3,3.7 \mathrm{~Hz}, 1 \mathrm{H}, 6-\mathrm{H}), 4.19$ (dd, $J=$ 12.0, $\left.5.3 \mathrm{~Hz}, 1 \mathrm{H}, \mathrm{CH}_{2} \mathrm{CO}_{2} \mathrm{CH}_{3}\right), 4.26\left(\mathrm{dd}, J=12.0,3.7 \mathrm{~Hz}, 1 \mathrm{H}, \mathrm{CH}_{2} \mathrm{CO}_{2} \mathrm{CH}_{3}\right), 4.94$ (dt, $J=7.5$, $1.4 \mathrm{~Hz}, 1 \mathrm{H}, 5-\mathrm{H}), 5.26(\mathrm{dd}, J=2.6,1.4 \mathrm{~Hz}, 1 \mathrm{H}, 4-\mathrm{H}), 6.11(\mathrm{~d}, J=8.9 \mathrm{~Hz}, 1 \mathrm{H}, 7 \mathrm{a}-\mathrm{H}) .{ }^{13} \mathrm{C}$ NMR 
$\left(\mathrm{CDCl}_{3}\right): \delta 20.7$ (q) and $20.8(\mathrm{q})\left(\mathrm{CH}_{3}\right), 50.5$ (d, C-3a), $63.5\left(\mathrm{t}, \mathrm{CH}_{2} \mathrm{OCOCH}_{3}\right), 67.0$ (d), 67.9 (d) and 68.3 (d) (C-4, C-5 and C-6), 100.3 (d, C-7a), 137.2 (s, C-3), 169.1 (s) and $170.5(\mathrm{~s})(\mathrm{C}=\mathrm{O})$. MS (m/z, \%): 416 [(M+Na) ${ }^{+}, 100 \%$. Anal. calcd. for $\mathrm{C}_{13} \mathrm{H}_{16} \mathrm{BrNO}_{8}: \mathrm{C}, 39.61 ; \mathrm{H}, 4.09 ; \mathrm{N}, 3.55$. Found: C, 39.72; H, 4.21; N, 3.42.

\section{Cycloaddition reaction to alkene 4}

Alkene 4 (114 mg, $1 \mathrm{mmol})$ was dissolved in ethyl acetate and there were added $\mathrm{NaHCO}_{3}(504$ $\mathrm{mg}, 6 \mathrm{mmol})$ and dibromoformaldoxime $(305 \mathrm{mg}, 1.5 \mathrm{mmol})$. The reaction mixture was stirred at room temperature for 2 days. After the solids were removed by filtration, the filtrate was concentrated and the residue was chromatographed on a silica gel column with hexane/ethyl acetate 8:1 as the eluent. From the column there were obtained in order of elution: compound 12 (125 mg), mixture of $\mathbf{1 2}$ and $\mathbf{1 3}$ in ratio 3:1 (40 mg) and compound $\mathbf{1 3}$ contaminated with a small amount of $12(16 \mathrm{mg})$.

(3aR,6R,6aS)-3-Bromo-6-(hydroxymethyl)-6,6a-dihydrofuro[3,4-d]isoxazol-4(3aH)-one (12). This compound was obtained as white solid $\mathrm{mp} 110-112{ }^{\circ} \mathrm{C}$ in $66 \%$ yield. $[\alpha]_{\mathrm{D}}{ }^{25}=-61.7^{\mathrm{o}}(\mathrm{c}$ 1.22, $\mathrm{CHCl}_{3}$ ). IR (Nujol): v 3500 (s), 1755 (vs), 1570 (w), 1300(s), 1220 (m), 1220(s), 1090 (s), $1150(\mathrm{~s}), 1010(\mathrm{~m}) \mathrm{cm}^{-1} .{ }^{1} \mathrm{H} \mathrm{NMR}\left(\mathrm{CDCl}_{3}\right): \delta 1.94$ (br s, $\left.1 \mathrm{H}, \mathrm{OH}\right), 3.89(\mathrm{~d}, J=12.1 \mathrm{~Hz}, 1 \mathrm{H}$ $\left.\mathrm{CH}_{2} \mathrm{OH}\right), 4.06\left(\mathrm{~d}, J=12.1 \mathrm{~Hz}, 1 \mathrm{H}, \mathrm{CH}_{2} \mathrm{OH}\right), 4.32$ (d, $\left.J=9.0 \mathrm{~Hz}, 1 \mathrm{H}, 3 \mathrm{a}-\mathrm{H}\right), 4.81(\mathrm{~d}, J=1.3 \mathrm{~Hz}$, $1 \mathrm{H}, 6-\mathrm{H}), 5.50(\mathrm{dd}, J=9.0,1.3 \mathrm{~Hz} 1 \mathrm{H}, 6 \mathrm{a}-\mathrm{H}) .{ }^{13} \mathrm{C} \mathrm{NMR}\left(\mathrm{CDCl}_{3}\right): \delta 59.2(\mathrm{~d}, \mathrm{C}-3 \mathrm{a}), 62.2(\mathrm{t}$, $\mathrm{CH}_{2} \mathrm{OH}$ ), 84.8 (d) and 85.0 (d) (C-6 and C-6a), 132.9 (s, C-3), 162.7 (s, C=O). MS (m/z, \%): 235 $\left(\mathrm{M}+, 8 \%\right.$ ). Anal. calcd. for $\mathrm{C}_{6} \mathrm{H}_{6} \mathrm{BrNO}_{4}: \mathrm{C}, 30.53 ; \mathrm{H}, 2.56 ; \mathrm{N}, 5.93$. Found: $\mathrm{C}, 30.81 ; \mathrm{H}, 2.61 ; \mathrm{N}$, 5.67 .

(3aR,4S,6aR)-3-Bromo-4-(hydroxymethyl)-3a,6a-dihydrofuro[3,4-d]isoxazol-6(4H)-one

(13). This compound was obtained with $11 \%$ yield as a pale yellow oil contaminated with a small amount of 12; ${ }^{1} \mathrm{H}$ NMR $\left(\mathrm{CDCl}_{3}\right): \delta 2.44$ (br s, $\left.1 \mathrm{H}, \mathrm{OH}\right), 3.77\left(\mathrm{~d}, J=12.2 \mathrm{~Hz}, 1 \mathrm{H}, \mathrm{CH} \mathrm{H}_{2} \mathrm{OH}\right)$, $4.05\left(\mathrm{~d}, J=12.2 \mathrm{~Hz}, 1 \mathrm{H}, \mathrm{CH}_{2} \mathrm{OH}\right), 4.13(\mathrm{~d}, J=9.0 \mathrm{~Hz}, 1 \mathrm{H} 3 \mathrm{a}-\mathrm{H}), 4.83(\mathrm{~s}, 1 \mathrm{H}, 4-\mathrm{H}), 5.51 \quad(\mathrm{~d}, J=$ $9.0 \mathrm{~Hz}, 1 \mathrm{H}, 6 \mathrm{a}-\mathrm{H}) .{ }^{13} \mathrm{C} \mathrm{NMR}\left(\mathrm{CDCl}_{3}\right): \delta 56.9(\mathrm{~d}, \mathrm{C}-3 \mathrm{a}), 63.0\left(\mathrm{t}, \mathrm{CH}_{2} \mathrm{OH}\right), 79.4(\mathrm{~d})$ and $79.6(\mathrm{~d})$ (C-6 каı C-4), 138.4 (s, C-3), 171.5 (s, C=O).

\section{Methoxylation of compound 7}

Compound 7 (189 mg, $0.5 \mathrm{mmol}$ ) was dissolved in methanol $(5 \mathrm{~mL})$ and there was added $\mathrm{K}_{2} \mathrm{CO}_{3}$ (552 mg, $4 \mathrm{mmol}$ ). The reaction mixture was stirred at room temperature for 3 days. After the solids were removed by filtration, the filtrate was concentrated and the residue was purified on a silica gel column with hexane/ethyl acetate $4: 1$ as the eluent. From the column there was obtained compound 14 (148 $\mathrm{mg})$.

(5R)-3-Methoxy-5-[(3a' $\left.R, 5^{\prime} S, 5 a^{\prime} S, 8 a^{\prime} S, 8 b^{\prime} R\right)-2^{\prime}, 2^{\prime}, 7^{\prime}, 7^{\prime}$-tetramethyltetrahydro-3a' $H$ bis[1,3]dioxolo[4,5-b:4',5'-d]pyran-5'-yl]-4,5-dihydroisoxazole (14). This compound was isolated as an oil in $90 \%$ yield. $[\alpha]_{\mathrm{D}}{ }^{25}=-68.8^{\circ}\left(c \quad 1.66, \mathrm{CHCl}_{3}\right)$. IR (Neat): $v 1610(\mathrm{~s}), 1250(\mathrm{~s})$, $1200(\mathrm{~s}), 1120$ (s), $1160(\mathrm{~s}), 1060$ (vs), 990 (s) cm ${ }^{-1} .{ }^{1} \mathrm{H}$ NMR $\left(\mathrm{CDCl}_{3}\right): \delta 1.33$ (s, 3H, $\left.\mathrm{CH}_{3}\right), 1.36$ $\left(\mathrm{s}, 3 \mathrm{H}, \mathrm{CH}_{3}\right), 1.44\left(\mathrm{~s}, 3 \mathrm{H}, \mathrm{CH}_{3}\right), 1.51\left(\mathrm{~s}, 3 \mathrm{H}, \mathrm{CH}_{3}\right), 3.01$ (dd , $\left.J=16.6,7.5 \mathrm{~Hz}, 1 \mathrm{H}, 4-\mathrm{H}\right), 3.09$ 
(dd, $J=16.6,9.0 \mathrm{~Hz}, 1 \mathrm{H}, 4-\mathrm{H}), 3.81\left(\mathrm{dd}, J=7.5,2.0 \mathrm{~Hz}, 1 \mathrm{H}, 5^{\prime}-\mathrm{H}\right), 3.85$ (s, 3H, $\left.\mathrm{OCH}_{3}\right), 4.32$ (dd, $\left.J=5.0,2.0 \mathrm{~Hz}, 1 \mathrm{H}, 8 \mathrm{~b}^{\prime}-\mathrm{H}\right), 4.41\left(\mathrm{dd}, J=7.5,2.0 \mathrm{~Hz}, 1 \mathrm{H}, 5 \mathrm{a}^{\prime}-\mathrm{H}\right), 4.62$ (dd, $J=7.5,2.0 \mathrm{~Hz}$, $\left.1 \mathrm{H}, 8 \mathrm{a}^{\prime}-\mathrm{H}\right), 4.86(\mathrm{dt}, J=9.0,7.5 \mathrm{~Hz}, 1 \mathrm{H}, 4-\mathrm{H}), 5.53\left(\mathrm{~d}, J=5.0 \mathrm{~Hz}, 1 \mathrm{H}, 3 \mathrm{a}^{\prime}-\mathrm{H}\right) .{ }^{13} \mathrm{C}$ NMR $\left(\mathrm{CDCl}_{3}\right): \delta 24.2(\mathrm{q}), 25.0(\mathrm{q}), 25.9(\mathrm{q})$ and $26.1(\mathrm{q})\left(\mathrm{CH}_{3}\right), 35.4(\mathrm{t}, \mathrm{C}-4), 57.3\left(\mathrm{q}, \mathrm{OCH}_{3}\right), 67.7(\mathrm{~d})$, 70.3 (d), 70.5 (d) and 70.8 (d) (C-5', C-5a', C-8a' and C-8b'), 78.9 (d, C-5), 96.3 (d, C-3a'), 108.8 (s) and 109.4 (s) $\left(C\left(\mathrm{CH}_{3}\right)_{2}\right), 168.3(\mathrm{~s}, \mathrm{C}-3)$. MS (m/z, \%): $352\left[(\mathrm{M}+\mathrm{Na})^{+}, 80 \%\right]$. Anal. calcd. for $\mathrm{C}_{15} \mathrm{H}_{23} \mathrm{NO}_{7}$ : C, 54.70; H, 7.04; N, 4.25. Found: C, 54.50; H, 7.14; N, 4.13.

\section{Reductive ring cleavage of isoxazoline 14}

A catalytic amount of Raney Ni (about $20 \mathrm{mg}$, washed 3 times with methanol) was added to a previously degassed solution of isoxazolidine $14(66 \mathrm{mg}, 0.3 \mathrm{mmol})$ and boric acid (30 $\mathrm{mg}, 0.5$ $\mathrm{mmol})$ in $\mathrm{MeOH}(5 \mathrm{~mL})$ under a hydrogen atmosphere (balloon). The mixture was stirred for 2 hours and then the crude reaction mixture was passed through Celite, concentrated and purified by column chromatography on silica gel using hexane/ethyl acetate 2:1 as the eluent. From the column there was obtained compound $\mathbf{1 5}(65 \mathrm{mg})$.

Methyl (3R)-3-hydroxy-3-[(3aR,5R,5aS,8aS,8bR)-2,2,7,7-tetramethyltetrahydro-3aHbis[1,3] dioxolo[4,5-b:4',5'-d]pyran-5-yl]propanoate (15). This compound was isolated as an oil in $98 \%$ yield. $[\alpha]_{\mathrm{D}}{ }^{25}=-42.3^{\circ}\left(c 0.55, \mathrm{CHCl}_{3}\right)$. IR (Neat): $v 1720$ (vs), $1240(\mathrm{~s}), 1200(\mathrm{~s})$, $1160(\mathrm{~s}), 1060$ (vs), 990 (s) cm ${ }^{-1} .{ }^{1} \mathrm{H}$ NMR $\left(\mathrm{CDCl}_{3}\right): \delta 1.32\left(\mathrm{~s}, 3 \mathrm{H}, \mathrm{CH}_{3}\right), 1.37\left(\mathrm{~s}, 3 \mathrm{H}, \mathrm{CH}_{3}\right), 1.46$ (s, $\left.3 \mathrm{H}, \mathrm{CH}_{3}\right), 1.51\left(\mathrm{~s}, 3 \mathrm{H}, \mathrm{CH}_{3}\right), 2.52$ (dd $\left., J=16.7,8.4 \mathrm{~Hz}, 1 \mathrm{H}, \mathrm{CH}_{2} \mathrm{CO}_{2} \mathrm{CH}_{3}\right), 2.86$ (dd, $J=$ $\left.16.7,3.0 \mathrm{~Hz}, 1 \mathrm{H}, \mathrm{CH}_{2} \mathrm{CO}_{2} \mathrm{CH}_{3}\right), 3.25(\mathrm{br} \mathrm{s}, 1 \mathrm{H}, \mathrm{OH}), 3.66(\mathrm{dd}, J=8.5,1.7 \mathrm{~Hz}, 1 \mathrm{H}, 5-\mathrm{H}), 3.71(\mathrm{~s}$, $\left.3 \mathrm{H}, \mathrm{OCH}_{3}\right), 4.19(\mathrm{dt}, J=8.4,3.0 \mathrm{~Hz}, 1 \mathrm{H}, \mathrm{CHOH}), 4.31$ (dd, $\left.J=5.0,2.3 \mathrm{~Hz}, 1 \mathrm{H}, 8 \mathrm{~b}-\mathrm{H}\right), 4.49$ (dd, $J=8.1,1.7 \mathrm{~Hz}, 1 \mathrm{H}, 5 \mathrm{a}-\mathrm{H}), 4.61(\mathrm{dd}, J=8.1,2.3 \mathrm{~Hz}, 1 \mathrm{H}, 8 \mathrm{a}-\mathrm{H}), 5.50(\mathrm{~d}, J=5.0 \mathrm{~Hz}, 1 \mathrm{H}, 3 \mathrm{a}-\mathrm{H})$. ${ }^{13} \mathrm{C}$ NMR $\left(\mathrm{CDCl}_{3}\right) \delta 24.1$ (q), 24.4 (q), 24.9 (q) and 25.9 (q) $\left(\mathrm{CH}_{3}\right), 37.7\left(\mathrm{t}, \mathrm{CH}_{2} \mathrm{CO}_{2} \mathrm{CH}_{3}\right), 51.7$ (q, $\left.\mathrm{OCH}_{3}\right), 66.6$ (d), 69.2 (d), 70.4 (d), 70.6 (d) and 70.7 (d) (C-5, C-5a, C-8a, C-8b and $\left.\mathrm{CHOH}\right)$, 96.4 (d, C-3a), 108.7 (s) and 109.3 (s) $\left(C\left(\mathrm{CH}_{3}\right)_{2}\right), 173.5$ (s, $\left.\mathrm{C}=\mathrm{O}\right)$. $\mathrm{MS}(\mathrm{m} / \mathrm{z}, \%): 355\left[(\mathrm{M}+\mathrm{Na})^{+}\right.$, $100 \%$ ]. Anal. calcd. for $\mathrm{C}_{15} \mathrm{H}_{24} \mathrm{O}_{8}$ : C, 54.21; H, 7.28. Found: C, 54.02; H, 7.35.

\section{Reduction of the ester 15}

A solution of the ester $15(33 \mathrm{mg}, 0.1 \mathrm{mmol})$ in dry diethyl ether $(3 \mathrm{~mL})$ was cooled at $0^{\circ}$ and there was added $\mathrm{LiBH}_{4}(8 \mathrm{mg}, 0.32 \mathrm{mmol})$ and the mixture was stirred for 2 hours under an $\mathrm{Ar}$ atmoshere. After that, some drops of ethyl acetate were added to destroy the excess of $\mathrm{LiBH}_{4}$ and the mixture was poured to ethyl acetate/water. The aqueous layer was washed 2 times with ethyl acetate and the combined organic layers washed with brine, dried and concentrated. The product was purified by silica gel column chromatography hexane/ethyl acetate 1:1 as the eluent. From the column there was obtained compound $\mathbf{1 6}(27 \mathrm{mg})$.

(1R)-1-[(3aR,5R,5aS,8aS,8bR)-2,2,7,7-tetramethyltetrahydro-3aH-bis[1,3]dioxolo

$[4,5-$ b:4',5'-d]pyran-5-yl]propane-1,3-diol (16). This compound was isolated as an oil in $90 \%$ yield. $[\alpha]_{\mathrm{D}}{ }^{25}=+46.2^{\circ}\left(c\right.$ 0.24, $\left.\mathrm{CH}_{3} \mathrm{OH}\right)$. IR (Neat): $v 3400(\mathrm{br}), 1245(\mathrm{~s}), 1200(\mathrm{~s}), 1160(\mathrm{~s}), 1060$ (vs), $990(\mathrm{~s}) \mathrm{cm}^{-1} .{ }^{1} \mathrm{H} \mathrm{NMR}\left(\mathrm{CDCl}_{3}\right): \delta 1.32\left(\mathrm{~s}, 3 \mathrm{H}, \mathrm{CH}_{3}\right), 1.37\left(\mathrm{~s}, 3 \mathrm{H}, \mathrm{CH}_{3}\right), 1.46\left(\mathrm{~s}, 3 \mathrm{H}, \mathrm{CH}_{3}\right), 1.53(\mathrm{~s}$, 
$3 \mathrm{H}, \mathrm{CH}_{3}$ ), 1.73-1.87 (m, 1H, $\left.\mathrm{CH}_{2} \mathrm{CH}_{2} \mathrm{OH}\right), 1.97-2.08$ (m, $1 \mathrm{H}, \mathrm{CH}_{2} \mathrm{CH}_{2} \mathrm{OH}$ ), 3.33 (br s, $1 \mathrm{H}, \mathrm{OH}$ ), $3.02(\mathrm{~d}, J=4.7 \mathrm{~Hz}, 1 \mathrm{H}, \mathrm{OH}), 3.63(\mathrm{dd}, J=8.1,2.1 \mathrm{~Hz}, 1 \mathrm{H}, 5-\mathrm{H}), 3.83-4.09$ (m, 3H, $\mathrm{CH}_{2} \mathrm{CH}_{2} \mathrm{OH}$ and $\mathrm{CHOH}$ ), $4.32(\mathrm{dd}, J=5.1,2.4 \mathrm{~Hz}, 1 \mathrm{H}, 8 \mathrm{~b}-\mathrm{H}), 4.48(\mathrm{dd}, J=8.1,2.1 \mathrm{~Hz}, 1 \mathrm{H}, 5 \mathrm{a}-\mathrm{H}), 4.63$ (dd, $J=8.1,2.4 \mathrm{~Hz}, 1 \mathrm{H}, 8 \mathrm{a}-\mathrm{H}), 5.53(\mathrm{~d}, J=5.1 \mathrm{~Hz}, 1 \mathrm{H}, 3 \mathrm{a}-\mathrm{H}) .{ }^{13} \mathrm{C} \mathrm{NMR}\left(\mathrm{CDCl}_{3}\right): \delta 24.4(\mathrm{q}), 24.9$ (q) and 26.0 (q) $\left(\mathrm{CH}_{3}\right), 35.4$ (t, $\left.\mathrm{CH}_{2} \mathrm{CH}_{2} \mathrm{OH}\right), 61.6$ (t, $\left.\mathrm{CH}_{2} \mathrm{CH}_{2} \mathrm{OH}\right), 69.7$ (d), 70.6 (d), 70.7 (d), 70.8 (d) and 71.0 (d) (C-5, C-5a, C-8a, C-8b and CHOH), 96.4 (d, C-3a), 108.7 (s) and 109.4 (s) $\left(C\left(\mathrm{CH}_{3}\right)_{2}\right)$. MS (m/z, \%): $327\left[(\mathrm{M}+\mathrm{Na})^{+}, 100 \%\right.$ ]. Anal. calcd. for $\mathrm{C}_{14} \mathrm{H}_{24} \mathrm{O}_{7}: \mathrm{C}, 55.25 ; \mathrm{H}, 7.95$. Found: C, 55.32; H, 8.01.

\section{References}

1. For books about nitrile oxide chemistry see: (a) Caramella, P; Grünanger, P. In 1,3-Dipolar Cycloaddition Chemistry Padwa, A.; Wiley: New York, 1984; Ch. 3. (b) Curran, D. P. Advances in Cycloaddition JAI Press, NY, 1988. (c) Torssell, K. B. G. Nitrile oxides, Nitrones and Nitronates in Organic Synthesis, VCH: Weinheim, 1988. (d) Nitrile Oxides, Nitrones and Nitronates in Organic Synthesis: Novel Strategies in Synthesis, 2nd Edn Feuer, H. Ed., Wiley: New Jersey, 2008.

2. Selected references: (a) Cardirola, P.; Ciancaglione, M.; De Amici, M.; De Micheli, C. Tetrahedron Lett. 1986, 27, 4647. (b) Halling, K.; Thomsen, I.; Torsell, K. B. G. Liebigs Ann. Chem. 1989, 985. (c) De Amici, M.; Magri, P.; De Micheli, C.; Cateni, F.; Bovara, R; Carrea, G.; Riva, S.; Casalone, G. J. Org. Chem. 1992, 57, 2825. (d) Griesbeck, A. G.; Hirt, G.; Peters, K.; Peters, E.; Shnering, H. Liebigs Ann. 1995, 619. (e) Bacher, E.; Demnitz, F. W. J.; Hurni, T. Tetrahedron 1997, 53, 14317. (f) Conti, P.; Dallanoce, C.; De Amici, M.; De Micheli, C.; Fruttero, R. Tetrahedron 1999, 55, 5623. (g) Foti, F.; Grassi, G.; Risitano, F.; Rotondo, E.; Zona, D. Synlett 2004, 1577. (h) Kociolek, M. G.; Straub, N. G.; Marton, E. J. Lett. Org. Chem. 2005, 2, 280. (i) Conti, P.; De Amici, M.; Roda, G.; Pinto, A.; Tamborini, L.; Madsen, U.; Nielsen, B.; Bräuner-Osborne, H.; De Micheli, C. Tetrahedron 2007, 63, 2249. (j) Plant, A.; Thompson, P.; Williams, D. M. J. Org. Chem. 2008, 73, 3714.

3. For a review on 1,3-dipolar cycloadditions of nitrile oxides in the synthesis of carbohydrate mimics see: Gallos, J. K.; Koumbis, A. E. Curr. Org. Chem. 2003, 7, 397.

4. Mancera, M.; Roffé, I.; Galbis, J. A. Tetrahedron 1995, 51, 6349.

5. (a) Coutouli-Argyropoulou, E.; Malamidou-Xenikaki, E.; Mentzafos, D.; Terzis, A. J. Heterocycl. Chem. 1990, 27, 1185. (b) Coutouli-Argyropoulou, E.; Thessalonikeos, E.; J. Heterocycl. Chem. 1992, 29, 251. (c) Coutouli-Argyropoulou, E.; Anastasopoulos, C. J. Heterocyclic. Chem. 1996, 33, 731. (d) Coutouli-Argyropoulou, E.; Pilanidou, P. Tetrahedron Lett. 2003, 44, 3755. (e) Coutouli-Argyropoulou, E.; Lianis, P.; Mitakou, M; Giannoulis, A.; Nowak, J. Tetrahedron 2006, 62, 1494.

6. (a) Argyropoulos, N. G.; Panagiotidis, T.; Coutouli-Agyropoulou, E.; Raptopoulou, A. Tetrahedron 2007, 63, 321. (b) Coutouli-Agyropoulou, E.; Xatzis, C.; Argyropoulos, N. G. 
Nucleosides Nucleotides \& Nucleic Acids 2008, 27, 84. (c) Argyropoulos, N.; Gkizis, P.; Coutouli-Agyropoulou, E. Tetrahedron 2008, 64, 8752. (d) Argyropoulos, N.; Gkizis, P.; Coutouli-Agyropoulou, E. Arkivoc 2008, (xvi), 223.

7. (a) Paton, R. M.; Young, A. A.; J. Chem. Soc., Chem. Commun. 1991, 132. (b) Paton, R. M.; Young, A. A. J. Chem. Soc., Chem. Commun. 1994, 993. (c) Paton, R. M.; Young, A. A. J. Chem. Soc., Perkin Trans. 1 1997, 629. (d) McGhie, K. E.; Paton R. M. Carbohydr. Res. 1999, 321, 24.

8. Selected references: (a) Chmielewski, M.; Kaluza, Z.; Belzecki, C.; Salanski, P.; Jurczak, J.; Adamowicz, H. Tetrahedron 1985, 41, 2441. (b) Hewson, A. T.; Jeffery, J.; Szezur, N. Tetrahedron Lett. 1995, 36, 7731. (c) Cardona, F. ; Valenza, S.; Picasso, S.; Goti, A.; Brandi, A. J. Org. Chem. 1998, 63, 7311. (d) Capozzi, G.; Falciani, C.; Menichetti, S.; Nativi, C.; Raffaelli, B. Chem. Eur. J. 1999, 5, 1748. (e) Weng, M.; Geyer, A.; Friemel, A.; Jochims, J. C.; J. Prakt. Chem. 2000, 342, 486. (f) Marzabadi, C. H.; Franck, R. W.; Schinazi, R. F. Biorg. Med. Chem. 2002, 10, 273. (g) Bartolozzi, A.; Pacciani, S.; Benvenuti, C.; Cacciarini, M.; Liguori, F.; Menichetti, S.; Nativi, C. J. Org. Chem. 2003, 68, 8529. (h) Dahl, R. S.; Finney, N. S. J. Am. Chem. Soc. 2004, 126, 8356.

9. Selected references: (a) Ondruš, V.; Orság, M.; Fišera, L.; Prónayová, N. Tetrahedron 1999, 55, 10425. (b) Martin-Vilá, M.; Hanafi, N.; Jiménez, J. M.; Álvarez-Larena, A. Piniella, J. P.; Branchadell, V.; Oliva, A.; Ortuño, R. M. J. Org. Chem. 1998, 63, 3581. (c) González, G.; Martín, M. V.; Paredes, M. C. Heterocycles 2000, 52, 237. (d). Alibés, R ; Álvarez-Larena, A.; de March, P.; Figueredo, M.; Font, J.; Parella, T.; Rustullet, A. Org. Lett. 2006, 8, 491. (e) Stecko, S.; Paśniczek, K.; Jurczak, M.; Urbańczyk-Lipkowska, Z.; Chmielewski, M. Tetrahedron: Asymmetry 2006, 17, 68. (f) Stecko, S.; Paśniczek, K.; Jurczak, M.; Urbańczyk-Lipkowska, Z.; Chmielewski, M. Tetrahedron: Asymmetry 2007, 18, 1085. (g) Rustullet, A.; Racamonde, M.; Alibés, R.; de March, P.; Figueredo, M.; Font, J. Tetrahedron 2008, 64, 9442.

10. (a) Houk, K. N.; Moses, S. R.; Wu, Y.-D.; Rondan, N. G.; Jäger, V.; Schohe, R.; Fronczek, F. R. J. Am. Chem. Soc. 1984, 106, 3880. (b) Raimondi, L.; Wu, Y.-D.; Brown, F. K.; Houk, K. N. Tetrahedron Lett. 1992, 33, 4409. (c) Luft, J. A. R.; Meleson, K.; Houk, K. N. Org. Lett. 2007, 9, 555.

11. (a) Trang, T.; Nguyen, M.; Gross, P. H.; Franz, A. H. Arkivoc 2005 (iv), 110. (b) Nguyen, M.; Olmstaid, L.; Bains, S.; Franz, A. H. Arkivoc 2007 (xiii), 235.

12. Pakulski, Z.; Zamojski A. Tetrahedron 1995, 51, 871.

13. (a) Vyas, D. M.; Chiang, Y.; Doyle, T. W. Tetrahedron Lett. 1984, 25, 487. (b) Calinaud, P.; Gelas, J. Synthesis of Isopropylidene, Benzylidene, and Related Acetals. In Preparative Carbohydrate Chemistry; Hanessian, S., Ed.; Marcel Dekker Inc.: New York, 1997, pp 3-33. (c) Mann, J.; Partlett, N. K.; Thomas, A. J. Chem. Research (S) 1987, 369. 